International Journal of Instruction e-ISSN: 1308-1470 • www.e-iji.net
October $2020 \bullet$ Vol.13, No.4

p-ISSN: 1694-609X

pp. 559-574

Received: 19/09/2019

Revision: 29/04/2020

Accepted: $18 / 05 / 2020$

OnlineFirst:06/08/2020

\title{
Cultural Diversity and its Influence on English Teaching and Learning in an EFL Context
}

\author{
Umiati Jawas
}

Universitas PGRI Kanjuruhan Malang, Indonesia,umiati_jawas@unikama.ac.id

\begin{abstract}
The main concept of foreign language education is that communication is a social interaction rather than a linguistic exchange. Despite a strong interconnectedness between language and culture in foreign language learning, learning of culture has not been integrated into the curricular goals. Designed in a descriptive case study, this study was conducted to discover the influence of cultural diversity on English teaching and learning process in an EFL class. The main research question was how the cultural diversity existing in the class was influencing the lecturer and students in their teaching and learning English. Data were collected through interview and questionnaire. Interview data were compiled from an English native speaker lecturer of a university class where the students came from different cities in Indonesia. Then, questionnaire was distributed to the students to know their cultural experiences in learning English and their perception of the role of cultural knowledge and understanding in their English language learning. The findings show that both the lecturer's and students' native culture do interfere with teaching and learning process. The implication of the findings underlines the importance to provide the opportunities for non-native English students to use the target language in its pragmatic functions through the selection of learning materials and classroom activities that can enhance their cultural knowledge and awareness.
\end{abstract}

Keywords: cultural diversity, cultural knowledge, cultural awareness, English teaching and learning, language pragmatic/social function

\section{INTRODUCTION}

One of the most important reason for learning a foreign language is the ability to communicate with people who do not speak the same native language (Furstenberg, 2010; Ho, 2009). Yet, just words are not enough in this communication process (Genc $\&$ Bada, 2005). The context of culture, in which the words will acquire their value and meaning (Baker, 2011; Baker, 2015; Genc \& Bada, 2005; Ho, 2009), is equally important. Culture can be generally defined as a system of ideas that control the attitude and behavior of human both individually and in groups. This concept of culture encompasses language among others cultural components. Understanding the cultural

\footnotetext{
Citation: Jawas, U. (2020). Cultural Diversity and its Influence on English Teaching and Learning in an EFL Context. International Journal of Instruction, 13(4), 559-574. https://doi.org/10.29333/iji.2020.13435a
} 
dimensions of a language is necessary to know how they are applied by those whose native language is different from the one being learned (Baker, 2011; Baker, 2015; Ho, 2009; Pulverness, 2003). The implication is that culture has to be integrated into foreign language teaching and learning for its meaningful use to take place. In learning a foreign language, the meaning of words determines the communication process (Baker, 2011; Genc \& Bada, 2005; Ho, 2009). Therefore, as argued by some scholars, social interaction is crucial in learning a foreign language for communication purposes rather than seeing it merely as linguistic conversation (Baker, 2011; Baker, 2015; Furstenberg, 2010; Scarino, 2010).

In spite of the interconnectedness between language and culture in foreign language learning, culture learning has not been integrated in curricular goals (Ho, 2009; Kearney, 2010). The lack of culture learning might materialize when a learner uses the acquired foreign language and realizes that his skills, grammar, or vocabulary are not enough to represent the implications of meanings (Genc \& Bada, 2005). The meanings of a word are the segment of personal or societal life to which they refer (Scarino, 2010). The variation in meanings is likely to lead to incorrect language use that cannot be solved by the learner's mastery of linguistic components (Genc \& Bada, 2005). Such a mistake is related not to any theory of language but to a theory of language users (Brooks, 1968). This moves the problem out of linguistics and into culture. It implies that teaching and learning process of a foreign language remains inaccurate and incomplete unless it is complemented by appropriate knowledge of the culture of the target language.

\section{REVIEW OF LITERATURE}

The main problem in teaching culture in the foreign language classroom is on the uncertainty of the meaning of the culture itself (Furstenberg, 2010). Although there have been the teaching activities devoted on culture teaching and textbook materials have included the cultural dimensions but there is still a continuous need to redefine the concept of culture that is meaningful in language classroom which is the first place that students encounter with another language (Furstenberg, 2010). The key challenge in revisiting the role of culture in the foreign language curriculum is to design a "more consistent educational framework that teaches language and culture in tandem, with its goal a joint literacy about a second language (L2) and culture (C2)" (Arens, 2010, p. 321). Therefore, the concept of culture should be expressed in terms that will be usable by those who teach and learn in school classroom. Although there is a preference to use culture-based foreign language courses instead of grammar-based syllabus, many teachers and textbooks continue to favor grammatical syllabus. This preference to grammatical approach does not require English speaking fluency of language teachers while at the same time it gives teachers classroom control and authority even in large classes, such approach has dominated foreign language teaching (Richards \& Rodgers, 2014).

However, empirical study has urged the importance to see how language is studied and learned in the target culture and to imitate or make appropriate adaptations of such procedures (Furstenberg, 2010). Although many language teachers have recognized 
such need for a cultural accompaniment to language acquisition, there has been lack of effort to encourage them to teach culture (Nault, 2008). The inadequacy of culture teaching in language learning is due to a number of limitations. First of all is the lack of cultural knowledge possessed by the teachers (Ho, 2009). As the sole authority in classrooms, the inadequacy of teachers' cultural knowledge might be the influential factor on students' language learning (Kramsch \& Sullivan, 1996). Next constraint is the availability of native English speakers. Although native speakers can be important cultural resource in language learning (Ho, 2009), many schools cannot afford to have native speakers to teach the language. Another limitation is on time allowance for culture teaching in each lesson or even the system of education itself (Ho, 2009). Consequently, cultural learning has not been an important component in foreign language teaching (Ho, 2009; Kearney, 2010).

The question now is how culture profiles are to be implemented in classroom. Galloway (1988) has proposed a framework for building cultural understanding based primarily on process skills that combine actual and sociolinguistic content. The framework suggests four primary categories of cultural understanding for instructional activities. The first category is convention with the aim is to help students recognize and understand how people in a given culture typically behave in common situations. Galloway identifies two types of conventions: context determined conventions, which includes extra- linguistic behaviors that are characteristics in a given situation and function-determined conventions related to sociolinguistic principles or conventional utterances that are used to perform tasks in context. The second category is connotation which deals with the many culturally significant meanings that are associated with words. As students examine their own networks of association they can begin to discover that the underlying meanings of words are determined by their cultural frame of reference. Certain words can evoke various feeling and images (Galloway, 1984).

The third category of Galloway's framework for building cultural understanding is conditioning that highlights the influence of someone's cultural frame of reference on their action. This category focuses on how people respond in culturally conditioned ways and how to understand behaviors that are different from their own without making any comparison with their own standards. For instructional activities, students need to learn how to interpret behaviors and to accept cultural differences to develop their understanding towards other cultures. The last category is comprehension. This category requires skills on analysis, hypothesis formation, and tolerance of ambiguity. According to Galloway (1985), the objective of comprehension can be attained by instructional activities that examine one's source of information, stereotypes and overgeneralization, and ways of conflict resolution.

The intertwined connection between cultural learning and foreign language teaching as shown by the literature review above has made it an interesting subject for examination and investigation. Many empirical studies especially on cultural learning and English teaching have been conducted in the context where English is the first, second and foreign language such as study done by Baker (2012), Byram (2012), Chapelle (2010), 
Furstenberg (2010), Ha (2007), Hui (2005), Kearney (2010), Kim (2004), Leveridge (2008), Liddicoat, (2002), Nugent and Catalano (2015), Schulz (2007), Shemshadsara (2011), Sinicrope, Norris and Watanabe (2007), and Tomlison and Musuhara (2004). Some of the studies focused on promoting cultural awareness during classroom instructions while others investigated issues related with cultural learning in English teaching. However, similar subject has not been much investigated in Indonesian classrooms as proved by limited publications on this matter. Therefore, this study was conducted to identify the influence of cultural diversity in EFL class on teaching and learning process particularly in Indonesian class setting.

\section{METHOD}

The key research question of this study was how the cultural diversity existing in an EFL class was influencing the lecturer and students in their English teaching and learning. To answer this research question, a descriptive case study design was selected. Case study was chosen as this design examines the particularity and complexity of a single case which is in this study was a culturally-diverse EFL class and to understand its activity (teaching and learning process) within the circumstances. As the use of multiple methods to collect and analyze data are encouraged and found to be mutually informative in case study research to provide a more interactive and comprehensive results of the problem being examined (Harrison, et al, 2017).

This study was conducted in one Speaking Class taught by an English native speaker approaching the end of the semester as the case. The lecturer and the students became the subject of this study. The lecturer was an American who was awarded Fulbright English Language Fellow Scholarship. She earned Bachelor of Art in Applied Linguistics and had a master degree in Teaching English as a Second Language (TESOL) from Trinity Western University, Langley, British Columbia, Canada. She was the rater for TOEFL and TOEIC exam at Educational Testing Service and had an extensive teaching experience from 2001. She taught English in South Korea and the Philippines before being awarded the scholarship to teach English in Indonesia. The second subject of this study was her Speaking Class students. All the students were in their first semester study. As the university is located in Malang, East Jawa, the majority of the students came from East Jawa following by Kalimantan, Madura, West Jawa, Sumatera and Sulawesi respectively. The class had 26 students with the demographic characteristics shown in Table 1 below:

Table 1

Student Demographic Characteristics

\begin{tabular}{lllll}
\hline Place of Origin & Number & Cultural Background & \multicolumn{2}{l}{ Gender } \\
\cline { 4 - 5 } & & & M & F \\
\hline Madura & 4 & Madurese & 3 & 1 \\
East Jawa & 10 & Javanese & 4 & 6 \\
West Jawa & 2 & Sundanese & 2 & 0 \\
Kalimantan & 6 & Banjarese and Dayak & 1 & 5 \\
Sulawesi & 2 & Gorontalo and Makasarese & 1 & 1 \\
Sumatera & 2 & Palembang and Lampung & 0 & 2 \\
\hline Total & 26 & & 14 & 12 \\
\hline
\end{tabular}




\section{Instruments}

The interviews with the lecturer were guided by the following points:

1. The influence of class cultural diversity on instructional process

2. The problems experienced when exposing target culture in instructional process

3. The instructional practices to bridge culture differences in the class

To interpret the interview data, inductive analysis guided by basic interpretative studies was incorporated to reduce and reconstruct data through coding and categorization processes (Ary, Jacobs, \& Sorensen, 2010). A distribution of questionnaire to the students was done in the second phase. The questionnaire had eight items to know the students' cultural experiences in learning English and their perception of the role of cultural knowledge and understanding in their English language learning. All items were constructed in Likert-scale. The questionnaire was pilot-tested and counted for its realibility using Cronbach's Alfa. The result of the realibility test using SPSS analysis showed a score of .83 which means the questionnaire was reliable.Content validity was used to measure the validity of the questionnaire. The questionnaire responses were analyzed using percentage analysis.

\section{FINDINGS}

\section{Interview Results with the Lecturer}

\section{The influence of class cultural diversity on instructional process}

There are three main influences of class cultural diversity on instructional process identified from the interview analysis. The first challenge was about how much the responsibility of the students for their own learning was as opposed to what the teacher was supposed to do for them.

"I noticed that in my classroom, my students tended to be submissive and relied too much on me as their teacher to direct their learning. This caused miscommunication and misunderstanding between me and my students during our learning activities and I had to make my learning expectation clear to my students." (Q1)

The second influence was on how the students used their linguistic knowledge into meaningful language practices.

"Social and cultural contexts can make the linguistic mastery of my students not enough. So, there is also sociolinguistic and pragmatic aspects of a language, an understanding of how to use language (Q2)

The last influence was on how to combine the linguistic aspects of a language with its cultural and pragmatic aspects.

"What I frequently noticed was that my students learned English in separation from its cultural aspects. .... Cross cultural misunderstanding is an interesting 
topic and I try in every class to include some aspects of culture in my teaching and learning activities." (Q3)

\section{Problems Experienced When Exposing Target Culture in Instructional Process}

There are three key problems when exposing target culture in instructional process. The most common problem was the tendency of her students to translate something directly from their native language and culture into the target language and culture.

"What I notice is that my students learn English by translating something directly from their language to English. .... So, it is thinking about the language from a functional view point and pragmatic view point rather than purely linguistic and purely translating it directly out from their own culture". (Q4)

The second problem was about the cultural richness existing in the class. It was not only the culture of the target language but also different cultures among the students could potentially create problems in instructional process.

"The difficulties are more that culture is a very sensitive topic. I think when I present things related with cultural aspects, I need to make them presented in a more acceptable way." (Q5)

The third problem was the existence of negativity toward cultural differences especially the occurrence of prejudice and stereotype against the target culture. Such occurrence might happen when students compare their own standards to respond to different cultural contexts and behaviors

"When my students talk about negative things, I ask them to look at it from the perspective of people who think differently because of their different upbringing. I find this way effective to promote cultural understanding in my class" (Q6)

\section{The instructional practices to bridge culture differences in the class}

In class situation, culture exposures and activities easily attracted the attention of the students because in carrying out the activities the students were focused more on the content of the activities.

"I notice that my students enjoy activities about culture more, talking more about the functional thing. They seem to cooperate more, listen more, and participate more and answer my questions." (Q7)

The next important thing about cultural exposures is the selection of materials that have cultural contents in them.

"So, what I have my students to do is to find and read about cultural misunderstanding between people from different cultural backgrounds and I have them to look at this case study and discuss about it. Such discussion will show their own cultural understanding. Such materials not only provide linguistic knowledge to the students but they also give the students the opportunity to practice the knowledge in the pragmatic situation." (Q8) 


\section{Student Questionnaire Results}

There were eight questionnaire items constructed to know the students' perception on the role of cultural knowledge and understanding in their English language learning. The first questionnaire item is to know whether the students have had any experiences in using English that require them to have the knowledge and understanding of English culture. The finding shown in Table 2 shows that in majority (80.8\%) the students had the experiences of applying their cultural knowledge when using English.

Table 2

Experience in Using English that Requires Cultural Knowledge

\begin{tabular}{lll}
\hline Questionnaire Option & $\mathrm{N}$ & Percentage \\
\hline a. ever & 21 & $80.8 \%$ \\
b. never & 5 & $19.2 \%$ \\
\hline Total & 26 & $100 \%$ \\
\hline
\end{tabular}

The second questionnaire item is to know the frequency of students' learning materials and discussions that focus and explain cultural understanding. $73.1 \%$ of the students said that their learning materials and discussions sometimes explained and discussed about cultural understanding. Less than $4 \%$ said that their learning materials and discussions always explained and talked about English culture. The findings can be seen in Table 3.

Table 3

Cultural Exposures in English Language Learning

\begin{tabular}{lll}
\hline Questionnaire Option & $\mathrm{N}$ & Percentage \\
\hline a. always & 1 & $3.8 \%$ \\
b. sometimes & 19 & $73.1 \%$ \\
c. rarely & 6 & $23.1 \%$ \\
d. never & 0 & $0 \%$ \\
\hline Total & 26 & $100 \%$ \\
\hline
\end{tabular}

The third questionnaire item is to know whether the students agree that the lack of cultural knowledge will disadvantage their English learning. As shown in Table 4, majority of the students $(84.6 \%)$ acknowledged that lack of cultural knowledge would disadvantage their English learning.

Table 4

Effect of the Lack of Cultural Knowledge on English Learning

\begin{tabular}{lll}
\hline Questionnaire Option & $\mathrm{N}$ & Percentage \\
\hline a. strongly agree & 5 & $19.2 \%$ \\
b. agree & 17 & $65.4 \%$ \\
c. disagree & 4 & $15.4 \%$ \\
d. strongly disagree & 0 & $0 \%$ \\
e. no opinion & 0 & $0 \%$ \\
\hline Total & 26 & $100 \%$ \\
\hline
\end{tabular}

The fourth is to know whether the students have ever experienced difficulty in using English because of the lack of their cultural knowledge. As shown in Table 5, high percentage of the students $(96.2 \%)$ reported that they ever experienced the difficulty. 
Table 5

Difficulty in Using English Due to Lack of Cultural Knowledge

\begin{tabular}{lll}
\hline Questionnaire Option & $\mathrm{N}$ & Percentage \\
\hline a. ever & 25 & $96.2 \%$ \\
b. never & 1 & $3.8 \%$ \\
\hline Total & 26 & $100 \%$ \\
\hline
\end{tabular}

The fifth is to know the types of difficulties the students experience in using English due to their lack of English culture. As shown in Table 6, 57.7\% of the students said that the difficulty was on using the appropriate word and expression. $38.5 \%$ of the students found the difficulty in comprehending English authentic material. 3.8\% of the students faced the difficulty when they had to use English in academic context.

Table 6

Types of Difficulties

\begin{tabular}{lll}
\hline Questionnaire Option & $\mathrm{N}$ & Percentage \\
\hline a. to use appropriate word and expression & 15 & $57.7 \%$ \\
b. to use English in social context & 0 & $0 \%$ \\
c. to use English in academic context & 1 & $3.8 \%$ \\
d. to comprehend English authentic material & 10 & $38.5 \%$ \\
e. other: & 0 & $0 \%$ \\
\hline Total & 26 & $100 \%$ \\
\hline
\end{tabular}

The sixth is to know how the students solve the difficulties in using English due to their lack of English culture. As shown in Table 7, 38.5\% of the students discussed with their friends to solve the difficulties. $30.8 \%$ of the students tried to solve the difficulty through reading textbooks and references. $26.9 \%$ of the students asked their lecturer to solve the difficulties. $3.8 \%$ of the students used the information from the other sources to solve the difficulty.

Table 7

Ways to Solve the Difficulties

\begin{tabular}{lll}
\hline Questionnaire Option & $\mathrm{N}$ & Percentage \\
\hline a. ask to the lecturer & 7 & $26.9 \%$ \\
b. discuss with friends & 10 & $38.5 \%$ \\
c. use textbooks and references & 8 & $30.8 \%$ \\
d. other: from movie & 1 & $3.8 \%$ \\
\hline Total & 26 & $100 \%$ \\
\hline
\end{tabular}

The seventh is to know students' agreement to make culture exposure as part of English learning. $23.1 \%$ of the students strongly agreed and $76.9 \%$ of the students agreed to include culture exposure into their English learning. The finding can be seen in Table 8. 
Table 8

Agreement on Culture Exposure as Part of English Learning

\begin{tabular}{lll}
\hline Questionnaire Option & $\mathrm{N}$ & Percentage \\
\hline a. strongly agree & 6 & $23.1 \%$ \\
b. agree & 20 & $76.9 \%$ \\
c. disagree & 0 & $0 \%$ \\
d. strongly disagree & 0 & $0 \%$ \\
e. no opinion & 0 & $0 \%$ \\
\hline Total & 26 & $100 \%$ \\
\hline
\end{tabular}

The last is to know whether the students agree that English non-native speaker lecturers should have sufficient knowledge and good understanding of English culture. As shown in Table 9, 69.2\% of the students strongly agreed and $26.9 \%$ of them agreed. No students disagreed with the statement and only less than $4 \%$ had no opinion on this matter.

Table 9

Cultural Knowledge of English Non-native Speaker Lecturers

\begin{tabular}{lll}
\hline Questionnaire Option & $\mathrm{N}$ & Percentage \\
\hline a. strongly agree & 18 & $69.2 \%$ \\
b. agree & 7 & $26.9 \%$ \\
c. disagree & 0 & $0 \%$ \\
d. strongly disagree & 0 & $0 \%$ \\
e. no opinion & 1 & $3.8 \%$ \\
\hline Total & 26 & $100 \%$ \\
\hline
\end{tabular}

\section{DISCUSSION}

The interview results with the native English speaker lecturer show that cultural exposures become unavoidable in class where the lecturer and students come from different cultural backgrounds. It becomes more significant when there is multi-cultural condition within the class where the students are from multi ethnic groups and carry with them distinctive cultural characteristics and practices. The students will bring along this cultural diversity into their class and use it as their cultural framework in learning the target culture. The cultural exposures are required not only to expose the students to the English culture itself but also to make them realize that cultural diversity among them can affect their learning. Such efforts to make the students accept the existing cultural diversity in their class are basically the ways to promote and build students' understanding, empathy and tolerance toward other cultures existing in their classroom.

The striking finding of the interview with the lecturer is about the influence of the students' multi-cultural background on their learning responsibility. In Indonesian culture, generally, the system is built and based on the hierarchy of authority (Bjork, 2005; Chan \& Sam, 2007; Kintamani, 2002; Raihani, 2007; Tilaar, 2009). As teachers have the highest authority in classroom, they have the right to decide the process and direction of learning. In this cultural system of learning, students tend to be submissive to the authority of their teacher to show their respect to their teacher (Kunandar, 2007; Taruna, 2007). Such cultural attitude is quite contrast with the independence of learning 
and personal learning responsibility known and highlighted in Western culture. These different cultural values of learning are likely the explanation for this first influence of cultural diversity on instructional process.

It is very clear that the contributing problem of the separation of language learning from its culture is how the students associate the meanings of their acquired learning of linguistics components into the cultural contexts. As argued by some scholars, mastery of linguistics components of a foreign language is not enough to understand the implications of meanings in the language (Genc \& Bada, 2005). As meanings are formed through cultural contexts, understanding of the cultural dimensions of the language becomes imperative for a meaningful use of the language (Baker, 2011; Baker, 2015; Ho, 2009; Pulverness, 2003).

The integrated approach applied by the lecturer is in line with the findings of empirical studies that have underlined the importance to understand the way the language is studied and learned in the target culture and to select appropriate way to adapt the way to the context where the language is learned ((Nault, 2008; Furstenberg, 2010; Shemshadsara, 2012; Young \& Sachdev, 2011). Such approach will make the students recognize the importance of cultural aspects in their language learning and increase their awareness of the need to integrate culture into their language learning. This will help them comprehend how the language is used in its authentic setting and adjust their way of learning it. Scholars like Nault (2008), Stern (1992), Young and Sachdev (2011) have pointed out the advantage of linguistic and cultural combination in foreign language learning. In addition, this integrated approach reflects convention; that is, the first category of Calloway's framework of cultural understanding. Convention is done to help students recognize and understand how people in a given culture typically behave in common situations. It deals with socio-linguistic and cultural context that determine the use of the language.

The most common problem faced in teaching English and exposing its culture is the tendency of the students to translate something directly from their native language and culture into the target language and culture. This implies that the students only used their linguistic knowledge of the language and neglected the pragmatic and cultural aspects of the language. The tendency of direct translation from students' native language to the target language is a common and, perhaps, natural thing taking place in foreign language classes as students will use their own language as the frame of reference in their foreign language learning. As every language is the product of the its society where the cultural convention in the society determines the meaning-making of the language, using certain language as a frame of reference in studying another language will result in erroneous use of the target language. Such language error relates to the theory of language users rather than the theory of language (Brooks, 1968).

The possibility of the occurrence of prejudice and stereotype in foreign language learning has been raised in the literature. According to the cultural understanding framework proposed by Galloway (1988), such occurrence might happen when students compare their own standards to respond to different cultural contexts and behaviors. To avoid such influence of students' cultural frame of reference on their action, they should 
be given instructional activities that promote their acceptance of behavior and cultural differences. The activities adopted by the lecturer to reduce the negativity of her students towards other cultures reflect the last category of Galloway's framework of building cultural understanding (1988). Her approach in asking her students to think from other people's perspective who come from different culture is basically about building her students' comprehension through developing their skills to analyze, formulate hypothesis and tolerate cultural differences and ambiguities. Such cultural awareness has been argued to be beneficial in language learning as it broadens the mind, increases tolerance and achieves cultural empathy and sensitivity of the learners (Tomlinson \& Musuhara, 2004).

From the questionnaire responses, they indicate that basically the students were aware that cultural knowledge was inseparable when the language was used. They also recognized the role of cultural knowledge in their language learning. The majority of the students acknowledged that this cultural knowledge improved their language understanding and agreed to make it as part of their language learning. Such supporting opinion on the important role of cultural knowledge was related to the difficulties they experienced when applying the language that required their knowledge of the culture. They agreed that the lack of cultural knowledge would disadvantage their English learning. Although many of the students agreed that their local lecturers should have sufficient knowledge and good understanding of English culture, many of the students prefered to solve the their difficulties through discussion with their friends rather than asking help from their lecturer. This may indicate that the lecturer has not been the authority the students seek help from to solve their difficulties in cultural knowledge. Such condition challenges the role of teachers in language learning. As scholars have pointed out that teachers' cultural knowledge determines students' language learning (Kramsch \& Sullivan, 1996). Therefore, teachers should include more cullture aspects in English language teaching and learning activities.

The underline is how English learning helps the students have an understanding and appreciation of how the language is used by the native speakers within the target language community (Stern, 1992). The instructional practices adopted by the lecturer support the findings of empirical studies that show the importance to integrate the culture into foreign language learning (Nault, 2008; Shemshadsara, 2012; Young \& Sachdev, 2011). The idea to give the students the opportunity to use their linguistic knowledge of the language into its pragmatic aspects is the paramount issue in teaching foreign language. It is not enough to equip students with only the linguistic aspects of the language but it is also imperative to teach them how to use the language in its real communicative functions. This consideration becomes more important in EFL setting because there is a limited language and cultural exposures to the students when they are outside the classroom. It even becomes more important when the classroom is multicultural. In such circumstance, the language instructional activities must not come against the sensitive issues related with class cultural diversity that can produce negative feelings among the class members. Instead, it should encourage students to look at how people in certain culture think about certain things. This cultural perspectives can affect 
the way students perceive different cultures including the target culture in their English learning.

\section{CONCLUSION}

Indeed, understanding the concept of target culture by those who teaches and studies English in different cultural setting is argued to be necessary (Nault, 2008; Young \& Sachdev, 2011). Reviews on related literature have shown that integrating culture into language learning is of importance (Shemshadsara, 2012). One of the most important aims of culture integration into language learning is to help the students have an understanding and appreciation of how the language is used by the native speakers within the target language community (Stern, 1992). Such cultural awareness has been a highlight in language learning as it broadens the mind, increases tolerance and achieves cultural empathy and sensitivity of the learners (Tomlinson \& Musuhara, 2004). Cultural awareness promotes three qualities among the students; that is, the awareness of one's own culturally-induced behavior, awareness of the culturally-induced behavior of others, and ability to explain one's own cultural standpoint (Tomalin \& Stempleski, 1993). As students' cultural awareness is developed through the recognition of their cultural identity in relation to other cultures, teachers should analyze students' actual and academic needs in terms of cultural knowledge, awareness or ability to function in proper ways (Tomalin \& Stempleski, 1993). This can be a direction for further research to investigate the role of cultural awareness in foreign language learning.

As a language is a product of a society, learning a language requires an understanding of the culture of the language. However, scholar has urged that culture teaching will not become a reality in the foreign language classroom until teachers are teaching more than form, that there is content to that which is being taught, a content that is not identified in terms of grammatical descriptors. The pedagogical implication of this study is that the teaching of culture must extend beyond factual learning. This again opens the opportunities for investigating the implementation of culture in language learning. Factsonly approach to the teaching of culture is not only insufficient but may also be detrimental in that it may at times reinforce stereotypes rather than diminish them. Therefore, in designing and deciding activities to promote culture exposures in language learning the students should have the opportunity to use the language in its functional and pragmatic features. Students must have the chance to use their linguistic understanding of the language and apply it into a situation that was meaningful and appropriate in its social and cultural context. It is challenging especially in EFL class where the lecturer and the students come from similar cultural background. The tendency is to ignore or even to neglect the cultural difference of the language that they are learning.

\section{ACKNOWLEDGEMENT}

The writer of this article as the researcher in this study would like to thank the research subjects who have participated in this study. 


\section{REFERENCES}

Arens, K. (2010). The field of culture: The standards as a model for teaching culture. The Modern Language Journal, 94(ii), 321-324.

Ary, D., Jacobs, L., \& Sorensen, C. (2010). Introduction to research in education. USA: Wadsworth Cengage Learning.

Baker, W. (2011). Intercultural awareness: Modelling an understanding of cultures in intercultural communication through English as a lingua franca. Language and Intercultural Communication 11(3), 197-214.

Baker, W. (2012). From cultural awareness to intercultural awareness: Culture in ELT. ELT Journal, 66(1), 62-70.

Baker, W. (2015). Research into practice: Cultural and intercultural awareness. Language Teaching 48(1), 130 - 141.

Bjork, C. (2005). Indonesian education: Teachers, schools and central bureaucracy. New York: Routledge.

Brooks, N. (1968). Teaching culture in the foreign language classroom. Foreign Language Annals 1(3), 204-217.

Byram, M. (2012). Language awareness and (critical) cultural awareness - relationships, comparisons and contrasts. Language Awareness, 21(1-2), 5-13.

Byram, M., \& Planet, M.T. (2000). Social identity and European dimension: Intercultural competence through foreign language learning. Graz: Council of Europe.

Chan, S., \& Sam, T. (2007). Analisis SWOT kebijakan pendidikan era otonomi daerah (SWOT analysis of educational policy in the era of regional autonomy). Jakarta, Indonesia: Penerbit PT RajaGrafindo Persada.

Chapelle, C.A. (2010). If intercultural competence is the goal, what are the materials? Proceedings of Intercultural Competence Conference, 1, 27-50.

Furstenberg, G. (2010). Making culture the core of the language class: Can it be done? The Modern Language Journal 94(ii), 329-332.

Galloway, V. B. (1984). Communicating in a cultural context. ACTFL master lecture series. Monterey, CA: Defense Language Institute.

Galloway, V. B. (1998). Constructing cultural realities: "Facts" and frameworks of association. In J. Harper, M. Lively, \& M. Williams (Eds.), The coming of age of the profession: Emerging issues in the teaching of foreign languages (pp. 129-140). Boston: Heinle and Heinle. 
Genc, B., \& Bada, E. (2005). Culture in language learning and teaching. The Reading Matrix 5 (1), 73-84.

Gobo, G. (2008). Doing ethnography. London: SAGE Publications Ltd.

Ha, P. L. (2007). Australian trained teachers of English culture and identity formation. Language, Culture and Curriculum, 20(1), 20-35. http://dx.doi.org/10.2167/lcc324.0.

Harrison, H., Birks, M., Franklin, R., \& Mills, J. (2017). Case study research: Foundations and methodological orientations. Forum: Qualitative Social Research, 18(1), art.19.

Ho, S. Thang. K. (2009). Addressing culture in EFL classrooms: The Challenge of shifting from a traditional to an intercultural stance. Electronic Journal of Foreign Language Teaching 6(1), 63-76.

Hui, D. (2005). False alarm or real warning? Implications for China of teaching. English Journal of Educational Enquiry, 6(1), 90-109.

Kearney, E. (2010). Cultural immersion in the foreign language classroom: Some narrative possibilities. The Modern Language Journal, 94(2), 332.

Kim, J. (2004). Coping with cultural obstacles to speaking English in the Korean secondary school context. Asian EFL Journal, 6(3).

Kintamani, I. (2002). Guru dan dinamikanya (Teachers and their dymanics). In Selintas pendidikan Indonesia di akhir 2002: 8 isu pendidikan (Brief review of Indonesian education at the end of 2002: 8 educational issues). Jakarta: Departemen Pendidikan Nasional Indonesia: Badan Penelitian dan Pengembangan Pusat Data dan Informasi Pendidikan.

Kramsch, C., \& Sullivan, P. (1996). Appropriate pedagogy. ELT Journal, 50(3), 199212. http://dx.doi.org/10.1093/elt/50.3.199.

Kunandar. (2007). Guru profesional: Implementasi Kurikulum Tingkat Satuan Pendidikan (KTSP) dan persiapan menghadapi sertifikasi guru (Professional teachers: Implemetation of School-Based Curriculum (SBC) and the preparation for teacher certification). Jakarta, Indonesia: Penerbit PT Raja Grafindo Persada.

Leveridge, A. N. (2008). The relationship between language and culture and the implications for language teaching. TEFL Articles. Retrieved from https://www.tefl.net/elt/articles/teacher-technique/language-culture/.

Liddicoat, A. J. (2002). Static and dynamic views of culture and intercultural language acquisition. Babel, 36(3), 4-11.

Nault, D. (2008). Going global: Rethinking culture teaching in ELT contexts. Language, Culture and Curriculum 19(3), 314-328. 
Nugent, K., \& Catalano, T. (2015). Critical cultural awareness in the foreign language classroom. Faculty Publications: Department of Teaching, Learning and Teacher Education. $\quad$ Paper $194 . \quad$ Retrieved from http://digitalcommons.unl.edu/teachlearnfacpub/194.

Pulverness, A. (2003). Distinctions \& dichotomies: Culture-free, culture-bound. Online documents at URL http://elt.britcoun.org.pl/forum/distanddich.htm.

Pulverness, A. (2004). Here and there: Issues in materials development for intercultural learning. Online Documents at URL http://elt.britcoun.org.pl/forum/handt.htm[25.06.2004].

Raihani. (2007). Education reforms in Indonesia in the twenty-first century. International Education Journal, 8(1)172-183.

Richards, J. S., \& Rodgers, T. S. (2014). approaches and methods in language teaching. Cambridge: Cambridge University Press.

Scarino, A. (2010). Assessing intercultural capability in learning languages: A renewed understanding of language, culture, learning, and the nature of assessment. The Modern Language Journal 94(ii), 324-328.

Schulz, R. A. (2007). The challenge of assessing cultural understanding in the context of foreign language instruction. Foreign Language Annals, 40(1), 9-26

Scott, D., \& Morrison, M. (2007). Key ideas in educational research. London: Continuum International Publishing Group.

Shemshadsara, Z. G. (2012). Developing cultural awareness in foreign language teaching. English Language Teaching V(3), 95-99.

Sinicrope, C., Norris, J., \& Watanabe, Y. (2007). Understanding and assessing intercultural competence: A sumnuston mary of theory, research, and practice. Second Language Studies, 26, 1-58.

Stern, H. H. (1992). Issues and options in language teaching. Oxford: Oxford U.

Taruna, T. (2007). Kurikulum yang mencerdaskan (Curriculum to educate). In Kurikulum yang mencerdaskan visi 2030 dan pendidikan alternatif (Curriculum to educate 2030 vision and alternative education) A. Indratno (ed). Jakarta, Indonesia: Penerbit Buku Kompas.

Tilaar, H. (2009). Membenahi pendidikan nasional (Fixing national education). Jakarta, Indonesia: Penerbit Rineka Cipta.

Tomalin, B., \& Stempleski, S. (1993). Cultural awareness. Oxford: Oxford U.

Tomlinson, B., \& Musuhara, H. (2004). Developing cultural awareness. MET, 13(1), 17. 
Young, T. J., \& Sachdev, I. (2011). Intercultural communicative competence: Exploring English language teachers' beliefs and practices. Language Awareness 20(2), 81-98. 